University for Business and Technology in Kosovo

UBT Knowledge Center

UBT International Conference

2017 UBT International Conference

Oct 29th, 5:00 PM - 5:15 PM

\title{
Insulting and Denigrating Language in Media
}

Anisa Rada

University for Business and Technology, anisa.rada@ubt-uni.net

Follow this and additional works at: https://knowledgecenter.ubt-uni.net/conference

Part of the Journalism Studies Commons

\section{Recommended Citation}

Rada, Anisa, "Insulting and Denigrating Language in Media" (2017). UBT International Conference. 201. https://knowledgecenter.ubt-uni.net/conference/2017/all-events/201

This Event is brought to you for free and open access by the Publication and Journals at UBT Knowledge Center. It has been accepted for inclusion in UBT International Conference by an authorized administrator of UBT Knowledge Center. For more information, please contact knowledge.center@ubt-uni.net. 


\title{
INSULTING AND DENIGRATING LANGUAGE IN MEDIA
}

\author{
Anisa Rada \\ UBT - Institucion i Arsimit të lartë, Lagjja kalabria, 10000 p.n., Prishtinë, Kosovë \\ anisa.rada@ubt-uni.net
}

\begin{abstract}
The Internet is a network that consists of millions of private, public, academic, business and government networks, both local and global, linked by a wide array of electronic, wireless, and optical networking technologies. By increasing the use of the Internet and the creation of computer networks has increased the significance of what is called "internet language". Since the internet gives space for free expression to everyone, this working paper aims to give examples and to reveal the fact that this freedom has been misused in the name of freedom of expression through hate speech, defamation and prejudice expressed through comments. Although there is not yet a mechanism that identifies hate speech and forbids its use, laws and institutions should be taken more seriously with the language used in social networks by creating a mechanism that helps prevent and identify this language.
\end{abstract}

Key words: internet, hate speech, slander, comments, social networks

\section{Introduction}

The Internet is a network that consists of millions of private, public, academic, business and government networks, both local and global, linked by a wide array of electronic, wireless, and optical networking technologies. By increasing the use of the Internet and the creation of computer networks has increased the significance of what is called "internet language". Since the internet gives space for free expression to everyone, this working paper aims to give examples and to reveal the fact that this freedom has been misused in the name of freedom of expression through hate speech, defamation and prejudice expressed through comments. Although there is not yet a mechanism that identifies hate speech and forbids its use, laws and institutions should be taken more seriously with the language used in social networks by creating a mechanism that helps prevent and identify this language.

\section{Global Village}

Now, it's easy to understand what Mc Luhan meant by saying that, the village is a good analogy to the internet world because people living in a village think that they know what's going on and are familiar with physical dynamics. 
The common language of this village is the language called "internet language". The reality is that they know very little and understand even less. It is a "global village", but more than McLuhan predicted. The most devastating people in a village are the gossipers. They distort information and destroy people.

97 In a global village, the most important media are gossipers. It is not the real world, nor a good approximation of it. It's the world that users want you to trust.

The internet makes more information available to more people, but makes it more difficult to determine its validity.

\section{News language on portals}

Internet is one of the greatest successes of the social media revolution, through the creation of large networks that share identities, entertainment, information and ideas among themselves. These media have now become the real spaces of opinion-making, which in the print and electronic media still remain a "tool", a politics in the hands and minds (in number) of analysts. In this network you can not avoid irresponsibility of some people and this makes the social media a scary and turbulent sea.

Internet is so big, so powerful and meaningless, that for some people, this is a complete replacement of life.

Having such a great impact on people and since it gives space to free expression to everyone, not rarely, reality gives us examples that this freedom has been misused in the name of freedom of expression, through hate speech, slander and prejudice, expressed through comments.

\section{"Delfi AS" case}

Such a case of misuse of this freedom comes from "Delfi AS", an important news portal in Estonia. In January of 2006, the portal published an article, considered honest and unbiased, in which, it informed that a ferry company was planning to destroy ice bridges, which were created by freezing sea water during the winter and which are passable for heavy vehicles, in order to secure its own transport bussines for passenger and freight ferries even in winter.

98 The article attracted many comments, 20 of which were threats and calls for violence against the main owner of the company, identified with initials L. Some of the comments openly demanded to beat and kill L.

After that, L asked the company to delete these comments and pay him a certain amount of money as a compensation for the damage. Delfi deleted the comments, but refused to pay the required amount as a compensation.

${ }^{97}$ Opinioni.al (2016), "Fshati global” në epokën e informacionit, sfida për të ndarë të vërtetën nga mashtrimi [online]http://opinion.al/fshati-global-ne-epoken-e-informacionit-sfida-per-te-ndare-teverteten-nga-mashtrimi/ (30.06.2017)

${ }^{98}$ Lapsi.al (2016), "Projektligji Bregu, riciklim i përpjekjes së qeverisë për të censuruar median" [online]http://www.lapsi.al/lajme/2016/10/22/projektligji-bregu-riciklim-i-p\%C3\%ABrpjekjes-

$\mathrm{s} \% \mathrm{C} 3 \% \mathrm{AB}$-qeveris $\% \mathrm{C} 3 \% \mathrm{AB}-\mathrm{p} \% \mathrm{C} 3 \% \mathrm{ABr}-\mathrm{t} \% \mathrm{C} 3 \% \mathrm{AB}$-censuruar-median\#.WTkeuGiGPcs $(30.06 .2017)$ 
L. complained to the Estonian courts, who considered the appeal fair and held Delfi responsible for not issuing threatening and inciting statements of violence against $\mathrm{L}$ and symbolically sentenced the portal to the sum of 320 euros. After this, most of the portals and different websites have closed the possibility of comments. This is done because of insults and direct threats to certain people, mentioned in the articles, for which, relevant portals hold the responsibility.

Therefore, it is said that the news end in the last comment, and not wanting to take responsibility, portals have closed the possibility of comments, however, despite this, these media have expanded their activity into social networks, like: Facebook, Twitter, Instagram, etc., which give to the people the opportunity of commenting again, but this time, everyone from their personal profiles, as a way of removing the responsibility from themselves.

With successive terrorist attacks, which are taking place in different parts of the world, particularly in Europe, recently, offensive and threatening statements have become more frequent and are inciting even more mass hatred.

\section{The case of hate speech, used after the terrorist attacks in France and Belgium}

${ }^{99}$ As a concrete example of such an impact are comments made after the terrorist attacks in Paris, Brussels and Nice. Only a few hours after the respective attacks, the "\#killallmuslims" hashtag, became the third phrase most commonly used in Spain and in many other parts of the world, deepening even more the crisis of refusing refugees across european countries and also causing hatred and Islamophobia among people.

\section{Cases of hate speech use, due to sexual orientation}

Another international case that shows the importance and impact that can have the comments of ordinary people in social networks is the case of transsexual Carla Antonelli, who as a member of the Madrid Assembly, received death threats via Twitter, just because of the protection of LGBT community rights.

Related to this topic, in September of 2016, football referee, Jesus Tomillero, also president of the association "Contra la LGBTFobia", in sport, received death threats on Twitter, just because he was the first and only male athlete in Spain that was openly self-declared as homosexual.

\footnotetext{
${ }^{99}$ Ajuntament.barcelona(2016), [online] http://ajuntament.barcelona.cat/bcnvsodi/wpcontent/uploads/2017/02/Informe_discurso-del-odio_ES-en-GB.pdf
} 


\section{The case of physical violence against Arbana Xharra}

As in many countries of the world, there are also many cases of threats and humiliations through comments in Kosovo. Such a case, which shows best the power of the internet and the words distributed through it, is the case of former journalist, now a member of PDK, Arbana Xharra.

Xharra was in journalism for 17 years and after that, she made a sudden decision to join the party she had repeatedly criticized during her work as a journalist. After this decision, she said she had had a very difficult journey with all her followers, but mostly, with journalists who once were her colleagues.

A few days after making the decision to adhere to PDK, Xharra became the victim of a physical assault, which for some analysts, is considered to have been caused or at least influenced by hate speech and insult to her.

Regarding this case, the former well-known journalist, who is very active on Facebook said that there were many insulting and threatening words in various comments.

"I have received threats on social networks, but never at this level," Xharra said.

100 Arbana Xharra was beaten near her apartment in Pristina after returning from a TV debate in Tirana. He was treated at the University Clinical Center of Kosovo, where she received medical help and after that, was issued for further treatment at home.

The physical attack on the PDK member, Arbana Xharra, from unknown people, has also been reported on the worldwide media.

\section{The case of Fahri Musliu}

${ }^{101}$ Long time ago, a croatian portal reported that Kosovo's well-known journalist, Fahri Musliu, was the biological father of Serbian Prime Minister Aleksander Vucic, based on the similarity of these two people, the article says in this portal, adding also the fact that in the past, journalist Musliu and mother of Serbian Prime Minister, had worked together on the Serbian Public Television (RTS). Later, journalist Musliu made a post where he reacted and denied categorically the fact that he could be the father of the Serbian Prime Minister.

In order to promote a tolerant and democratic society in Kosovo through respect of international standards of human rights and freedom of expression and for the prevention of the language of Defamation and Insult, the Parliament of Kosovo adopted the following Civil Law:

\section{CIVIL LAW AGAINST DEFAMATION AND INSULT}

The objective of this law is to regulate civil liability for defamation and insult while ensuring:

\footnotetext{
${ }^{100} \mathrm{http}: / /$ telegrafi.com/?s=ArbanawXharra $(30.06 .2017)$

${ }^{101} \mathrm{http}$ //zeri.info/aktuale/3068/fahri-musliu-e-njoh-nenen-e-vucic-por-nuk-jam-babai-i-tij/

(11.07.2017)
} 
a) the right to freedom of expression, as guaranteed by the Constitutional Framework on Provisional

Self-Government in Kosovo (UNMIK Regulation 2001/9 dated 15 May 2001) and the European Convention for the Protection of Human Rights and Fundamental Freedoms;

b) that the rules relating to defamation and insult do not place unreasonable limits on freedom of expression including and the publication and discussion of matters of public interest and importance;

c) effective and appropriate compensation for persons whose reputation was harmed by defamation and insult;

d) the essential role of media in the democratic process as public watchdogs and transmitters of information to the public.

\section{The terms used in this Law have the following meaning:}

Defamation shall mean the publication of a untrue fact or statement and the publisher knows or should know that the fact or the statement is untrue, the meaning of which injures the reputation of another person. Insult shall mean the statement, behavior, or publication of a statement directed at another person that is humiliating.

\section{MEASURES FOR PROTECTION FROM DEFAMATION AND INSULT}

\section{Article 4}

\section{Action against Defamation and Insult}

1024.1. A person has the right to demand to stop the defamation and insult and to demand that it will not be repeated in the future, the refutation of defamatory or insulting information concerning his/her person and compensation for moral and material damage caused by the defamation and insult, through a court proceeding, unless one of the exemptions to liability is established in accordance with this Law.

4.2. If defamation and insult is made through a mass medium, compulsory, it shall be refuted in the same mass medium and be given the same prominence. The refutation shall be published within eight (8) days of receipt of the relevant demand in the case of daily newspapers on the same page where the defamation and insult was published, in the next issue of a periodical or a telegraph

${ }^{102}$ gzk.rks-gov.net (2016), LIGJI CIVIL KUNDËR SHPIFJES DHE FYERJES [online] https://gzk.rks-gov.net/ActDocumentDetail.aspx?ActID=2503 
agency and within eight (8) days in the same manner or at the same time of day in case of broadcast information.

4.3. Where the defamation or insult identifies a child, the parent or legal guardian may initiate the procedure against defamation and insult before the competent court according to this Law.

4.4. Where the defamatory or insulting information identifies a deceased person, the first-degree heir of that person may initiate the procedure against defamation and insult before the competent court 3 according to this Law, under the condition that the defamation and insult caused harm to the reputation

of the heir.

\section{Chapter III}

\section{RESPONSIBILITY}

Article 5

Responsibility for Defamation and Insult

5.1. A person is responsible for defamation or insult if he/she made or disseminated the expression

of

defamation or insult, unless one of the exemptions to liability is established in accordance with

Law.

5.2. For defamation or insult made through media outlets the following may be held jointly or individually responsible: author, editor or publisher or someone who otherwise exercised control over its

contents.

5.3. Where the defamation or insult relates to a matter of public concern or the injured person is or was a public official or is a candidate for public office, there may only be responsibility for defamation

or insult if the author knew that the information was false or acted in reckless disregard of its veracity.

5.4. Public authorities are barred from filing a request for compensation of harm for defamation

insult.

Public officials may file a request for compensation of harm for defamation or insult privately

exclusively in their personal capacity. 
No one shall be liable for defamation and insult for a statement on a matter of public concern if they establish that it was reasonable in all the circumstances for a person in their position to have

disseminated the material in good faith, taking into account the importance of freedom of expression

with respect to matters of public concern to receive timely information relating to such matters.

\section{Press Council of Kosovo and its Code}

Although it has no executive role and power, however, in attempting to regulate the function of the print and online media and to regulate itself, the media have created a selfregulatory institution, which is known as the "Press Council of Kosovo", in which are members almost all printed and online media of Kosovo.

Press Council of Kosovo is a self-regulatory body founded for and by the print media sector in Kosovo. Its mission is based on the convictions of the Press Code of Kosovo.

"Freedom of speech, the right of citizens to be duly and completely informed and the respect for the Press Code of Kosovo are the foundations on which the Press Council is founded. The aim of Press Council of Kosovo is to protect the citizens from false information and the journalists from baseless complaints", is written in this Code.

\section{The Kosovo Press Council Code includes: \\ - General Provisions \\ - Reporting the Truth \\ - Encouraging and hate speech \\ - Right to respond \\ - Persons charged with criminal offenses \\ - Protection of children and minors \\ - Corruption and Bribery \\ - The authors' rights \\ - Advertising and sponsorship \\ - Guidelines for Online Journalism}

This function is also covered by UNMIK Regulation 2000/36, section 2.2, on the conditions of print media in Kosovo (Press Council of the Media, Code of Conduct for Electronic Media). (KMSH Brochure, 2016)

${ }^{103}$ Brochure KMSH,(2016). 
Although there is not yet a mechanism that identifies hate speech and forbids its use, laws and institutions should be taken more seriously with the language used in social networks, by creating a mechanism that helps prevent and identify this language. 


\section{References:}

1. Gazetadita.al (2016), A po e prish interneti gjuhën shqipe? http://www.gazetadita.al/apo-e-prish-interneti-gjuhen-shqipe/ (29.06.2017)

2. Opinioni.al (2016), "Fshati global" në epokën e informacionit, sfida për të ndarë të vërtetën nga mashtrimi [online]http://opinion.al/fshati-global-ne-epoken-e-informacionitsfida-per-te-ndare-te-verteten-nga-mashtrimi/ (30.06.2017)

3. Lapsi.al (2016), "Projektligji Bregu, riciklim i përpjekjes së qeverisë për të censuruar median" [online]http://www.lapsi.al/lajme/2016/10/22/projektligji-bregu-riciklim-ip\%C3\%ABrpjekjes-s\%C3\%AB-qeveris\%C3\%AB-p\%C3\%ABr-t\%C3\%AB-censuruarmedian\#.WTkeuGiGPcs (30.06.2017)

4. Ajuntament.barcelona(2016), http://ajuntament.barcelona.cat/bcnvsodi/wpcontent/uploads/2017/02/Informe_discurso-del-odio_ES-en-GB.pdf (01.07.2017)

5. http://telegrafi.com/?s=ArbanawXharra (30.06.2017)

6. gzk.rks-gov.net (2016), LIGJI CIVIL KUNDËR SHPIFJES DHE FYERJES https://gzk.rks-gov.net/ActDocumentDetail.aspx?ActID=2503

7. http://zeri.info/aktuale/3068/fahri-musliu-e-njoh-nenen-e-vucic-por-nuk-jam-babai-i-tij/ (11.07.2017)

8. http://www.gazetaexpress.com/lajme/a-eshte-shqiptar-kryeministri-i-serbise$51867 /$ ?archive $=1 \quad(11.07 .2017)$ 